\title{
KECERNAAN BAHAN KERING DAN BAHAN ORGANIK KAMBING KACANG JANTAN YANG DIBERI NAUNGAN DAN TANPA NAUNGAN DI LAHAN KERING KEPULAUAN
}

\section{Molbeka Marthina Manikari1), Bambang Hadisutanto'1), Jacobus S. Oematan'), Bachtaruddin Badewi1)}

\author{
1) Jurusan Peternakan, Politeknik Pertanian Negeri Kupang, \\ J. Prof. Dr. Herman Yohanes Lasiana Kupang P.O.Box. 1152, Kupang 85011 \\ Korespondensi: bhadisutanto@gmail.com
}

\begin{abstract}
Heat stress due to high ambient temperature results in uncomfortable livestock and unfavorable physiological changes. This condition causes livestock to not be able to maintain the balance of thermal energy, water, hormonal, mineral and feed consumption and consumption of dry matter is reduced so that digestibility of dry matter and organic matter also decreases. The purpose of this study was to determine the digestibility of dry matter and organic material of male goats in the shed without shade and with shade. The materials used in this study were 1 year old male goat, animal feed in the form of gamal leaves (Gliricidia sepium) and elephant grass, anthelmintic levamison, concentrated feed consisting of yellow corn flour, rice bran, soybean meal. and pollard.Variables observed included dry matter digestibility and organic matter digestibility. The research design used was placing 14 goat nuts allocated in 2 places, 7 of which were placed in a shed with 7 shelters and placed in a shed without a shade. Then the research data were analyzed using the $t$ test (t-student).The results of this study are the digestibility of dry matter and organic material of male goat without shade and with no significant shade $(P>0.05)$
\end{abstract}

Keywords: Kacang Goat, Dry material digestibility, Organic material digestibility

\section{PENDAHULUAN}

Salah satu masalah dalam memelihara ternak di daerah tropis adalah suhu udara yang panas. Keadaan ini, terutama dimusim kemarau mempunyai pengaruh negatif terhadap produktivitas ternak. Al-Dawood (2017) mengemukakan bahwa cekaman panas karena ternak berada pada suhu lingkungan tinggi mengakibatkan ternak tidak nyaman dan terjadi perubahan fisiologis yang tidak menguntungkan. Kondisi ini menyebabkan ternak tidak dapat memertahankan keseimbangan energi thermal, air, hormonal, dan mineral. Respon homeostasis yang umum terjadi adalah naiknya laju pernafasan, suhu tubuh, dan konsumsi air, sedangkan konsumsi pakan dan konsumsi bahan kering berkurang sehingga kecernaan bahan kering dan bahan organik juga mengalami penurunan.

Bagi ternak ruminansia, cekaman panas akibat suhu udara tinggi di luar batas toleransi ternak merupakan salah satu faktor lingkungan yang berpengaruh 
negatif. Tubuh ternak tidak mampu membuang panas tubuh yang dihasilkan dari pencernaan pakan (heat increment). Respon fisiologis ternak akan berakibat berkurangnya konsumsi pakan 6-30\%, produksi susu 15-20\%, dan fertilitas 40-50\%. Perubahan tingkah laku yang terjadi akibat cekaman panas adalah ternak meminimalkan pergerakannya, mencari tempat berteduh, mengubah aktivitas makan kewaktu di mana suhu udara lebih rendah, mengurangi konsumsi pakan, lebih memilih mengonsumsi konsentrat dari pada pakan kasar untuk mengurangi heat increment, dan ternak mengonsumsi air lebih banyak (Sireli dkk., 2017).

Suhu udara tinggi disertai kelembaban tinggi ternyata memang memberikan cekaman panas lebih tinggi dan efek negatif yang lebih besar pada ternak daripada suhu tinggi-kelembaban rendah. Chaidanya dkk,. (2017) melaporkan suatu percobaan terhadap kambing jantan Osmanabadi di India yang dipelihara dalam kandang bernaung dengan suhu maksimum $35,6^{\circ} \mathrm{C}$ dan tidak bernaung dengan

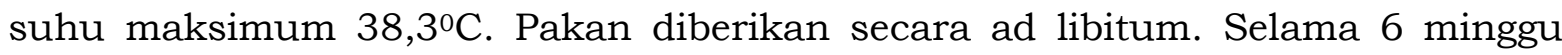
percobaan, konsumsi bakan kering dan kecernaan tidak berbeda antara kedua perlakuan. Selama tiga minggu pertama perubahan bobot badan juga tidak berbeda, sedangkan pada 3 minggu berikutnya ternak-ternak yang tidak memeroleh naungan menghasilkan perubahan bobot badan yang lebih rendah. Dikemukakan pula bahwa bangsa kambing tersebut mempunyai daya adaptasi cukup baik terhadap suhu lingkungan panas, namun cekaman panas mengakibatkan performans yang lebih rendah.

Suhu lingkungan tinggi mengakibatkan perubahan fisiologi dasar dari rumen. Temperatur tinggi mengurangi pergerakan saluran pencernaan, ruminasi dan kontraksi rumen, serta konsumsi pakan berkurang. Cekaman panas mengurangi total produksi VFA dengan variasi antar individu ternak, juga menghasilkan perubahan pada $\mathrm{pH}$ rumen. Perubahan pada komposisi mikroba rumen akibat cekaman panas bisa mengubah pola fermentasi dalam rumen yang menghasilkan variasi dalam kecernaan, produksi VFA, dan emissi gas methan.

Tujuan penelitian adalah untuk mengetahui kecernaan bahan kering dan kecernaan bahan organik kambing kacang jantan pada kandang tanpa naungan dan dengan naungan.

\section{METODE PENELITIAN}

\section{Tempat dan Waktu}

Penelitian dilakukan selama 3 bulan di kandang kambing percobaan UPT 
Kewirausahaan Politeknik Pertanian Negeri Kupang.

\section{Bahan dan Peralatan}

Bahan yang digunakan dalam penelitian ini adalah ternak kambing kacang jantan umur 1 tahun, pakan hijauan ternak berupa daun gamal (Gliricidia sepium) dan rumput gajah (Penisetum purpureum), Obat cacing (anthelmintic levamison), Pakan konsentrat yang terdiri dari tepung jagung kuning, dedak padi, bungkil kedelei dan pollard.

Alat yang digunakan antara lain Timbangan duduk (digital) merk Defender kapasitas $150 \mathrm{~kg}$, terpal, karung kapasitas $50 \mathrm{~kg}$, mixer vertikal merek Robhan kapasitas $750 \mathrm{~kg}$, mesin jahit merek Newlong ,ember, timbangan digital merk Krisbow kapasitas $5 \mathrm{~kg}$, plastik klip dan spuit volume $5 \mathrm{ml}$.

\section{Variabel yang Diamati dan Teknik Pengukurannya}

Variabel yang diamati meliputi kecernaan bahan kering dan kecernaan bahan organik.

1. Kecernaan Bahan Kering (BK)

Bahan kering (BK) adalah total zat-zat pakan selain air dalam suatu bahan pakan. Kecernaan bahan kering diukur untuk mengetahui jumlah zat makanan yang diserap oleh tubuh dengan menggunakan analisis jumlah bahan kering ransum maupun dalam feses (Tillman, dkk., 1998). Perhitungan kecernaan Bahan Kering (Dhana, 2008) :

$$
\text { Kecernaan BK(\%) }=\frac{\text { Konsumsi BK(gr) }- \text { Feses BK(gr) }}{\text { Konsumsi BK(gr) }} \times 100 \%
$$

Keterangan Rumus : BK = Bahan Kering

2. Kecernaan Bahan Organik (BO)

Bahan Organik (BO) merupakan bahan kering yang telah dikurangi abu. Nilai kecernaan bahan organik (KBO) didapatkan melalui selisih kandungan bahan organik (BO) awal sebelum inkubasi dan setelah inkubasi, proporsional terhadap kandungan BO sebelum inkubasi tersebut (Blümmel dkk., 1997).

Perhitungan kecernaan bahan organik (Dhana 2008) :

$$
\text { Kecernaan B0(\%) }=\frac{\text { Konsumsi B0(gr) }- \text { Feses B0(\%) }}{\text { Konsumsi B0(gr) }} \times 100 \%
$$

Keterangan Rumus : $\mathrm{BO}=$ Bahan Organik 


\section{Prosedur Penelitian}

1) Tahap Persiapan

Meliputi pembuatan kandang sebanyak 14 unit dengan 7 kadang diberi naungan dan 7 kandang tidak diberi naungan. Membuat konsentrat dengan bahan baku jagung giling, dedak padi, pollard dan bungkil kacang kedelei. Menyiapkan kambing kacang jantan umur \pm 1 tahun sebanyak 14 ekor. Menimbang ternak kambing kacang sebagai bobot awal ternak. Pemberian obat cacing pada ternak kambing sebanyak $5 \mathrm{ml}$ per ekor ternak. Melakukan pengacakan ternak kambing dan mengadaptasi ternak kambing selama 2 minggu.

2) Tahap Penelitian

Meliputi menempatkan kambing kacang jantan pada kandang penelitian selama 5 minggu yang terbagi 1 minggu kambing kacang proses adaptasi dan 4 minggu proses penelitian dan pengambilan data. Pemberian konsentrat pada pagi hari dan dilanjutkan dengan pemberian hijauan. Pemberian air minum diberikan secara adlibitum. Mengukur jumlah pakan yang diberikan dan jumlah pakan yang sisa dari ternak kambing setiap hari. Mengukur jumlah air minum yang sisa setiap pagi dengan selang waktu 24 jam. Pada minggu ketiga sampai minggu keempat dilakukan pengambilan feses dari setiap ternak kambing berturut-turut selama 3 hari (Jems,dkk., 2014). Feses yang baru diambil ditimbang bobot segarnya kemudian dikeringkan dengan panas matahari selama 3 hari. Feses yang telah kering matahari ditimbang berat keringnya kemudian diambil sampel \pm 20 gr untuk dianalisis di Laboratorium. Sampel hijauan pakan (rumput gajah dan daun gamal), konsentrat dan sampel feses dianalisis bahan kering dan bahan organik. Pengukuran kecernaan kambing kacang dilakukan di Laboratorium sesuai rumus perhitungan kecernaan bahan kering dan kecernaan bahan organik.

\section{Rancangan Percobaan dan Analisis Data}

Rancangan penelitian yang digunakan yaitu menempatkan ternak kambing kacang berjumlah 14 ekor dialokasikan pada 2 tempat yaitu 7 ekor ditempatkan pada kandang dengan naungan dan 7 ekor ditempatkan pada kandang tanpa naungan. Selanjutnya data penelitian ditabulasi dan dianalisis menggunakan uji t ( $t$-student). 


\section{HASIL DAN PEMBAHASAN}

\section{Bahan Kering dan Bahan Organik feses kambing kacang pada Kandang Naungan dan Tanpa Naungan}

Bahan kering dan bahan organik feses dari ternak kambing pada kandang naungan dan tanpa naungan dapat dilihat pada Grafik 1.

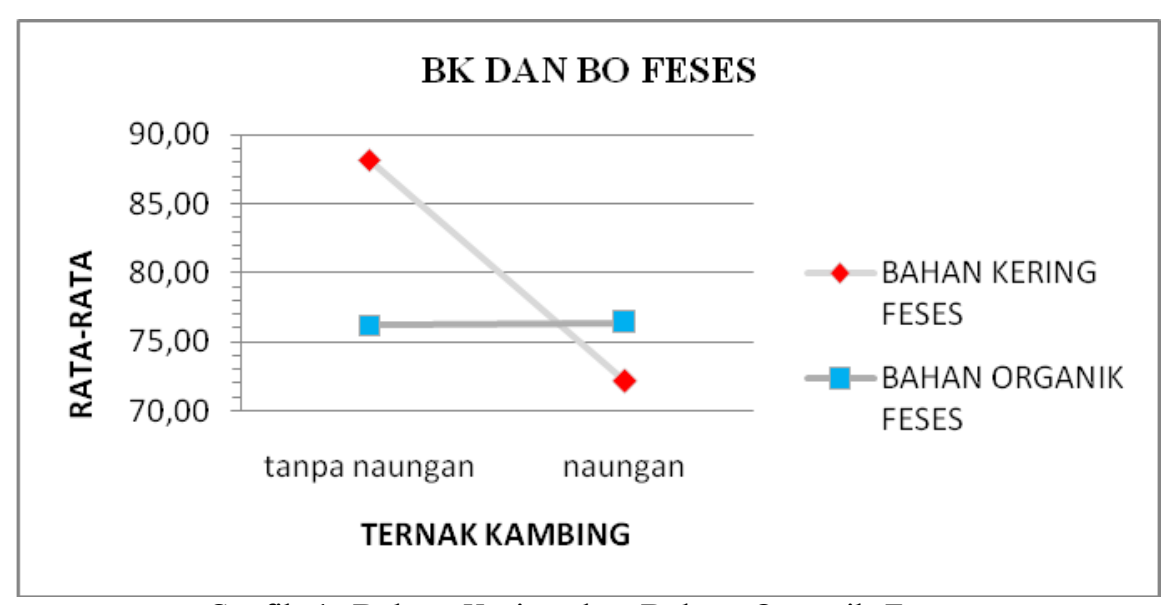

Grafik 1. Bahan Kering dan Bahan Organik Feses

\section{Pengaruh Cekaman Panas terhadap Kecernaan Bahan Kering Kambing Kacang Jantan}

Bahan kering $(\mathrm{BK})$ adalah total zat-zat pakan selain air dalam suatu bahan pakan. Kecernaan bahan kering diukur untuk mengetahui jumlah zat makanan yang diserap oleh tubuh dengan menggunakan analisis jumlah bahan kering ransum maupun dalam feses (Tillman, dkk., 1998).

Hasil penelitian kecernaan bahan kering kambing kacang jantan dapat dilihat pada Tabel 1.

Tabel 1. Kecernaan Bahan Kering (\%) pada Kambing Kacang Jantan

\begin{tabular}{llc}
\hline & \multicolumn{2}{c}{ Perlakuan } \\
\cline { 2 - 3 } Variabel & Tanpa Naungan & Naungan \\
\hline Kecernaan BK $(\%)$ & $56.43 \pm 4.31$ & $59,61 \pm 3,21$ \\
\hline Keterangan: Tidak signifikan $(P>0,05)$ & &
\end{tabular}

Adapun rataan persentase kecernaan bahan kering pada Tabel 2 dari kelompok ternak yang tanpa naungan adalah $56.43 \pm 4,31 \%$ sedangkan yang bernaungan adalah 59,61 $\pm 3,21 \%$. Meskipun terlihat berbeda kecernaan bahan kering untuk kandang naungan sedikit lebih tinggi dari kandang tanpa naungan 
namun hasil uji statistika ( $t$ - test) menunjukkan bahwa persentase kecernaan bahan kering dari kedua kelompok perlakuan tidak berbeda nyata $(P>0,05)$.

Perlakuan tidak berpengaruh nyata terhadap kecernaan bahan kering karena ternak sudah terbiasa dengan lingkungan atau dengan kata lain sudah beradaptasi, di mana sistem pemeliharaan ternak kambing di NTT masih secara tradisional atau semi intensif yaitu memelihara kambing di padang penggembalaan dan di kandang, sehingga ternak kambing kacang yang digunakan dalam penelitian sebelumnya sistem pemeliharaan digembalakan pada siang hari dan dikandangkan pada malam hari. Hal ini menyebabkan ternak kambing sebelum diberi perlakuan sudah beradaptasi dengan lingkungan sehingga saluran pencernaan ternak kambing sudah terbiasa mencerna pakan pada kondisi lingkungan yang panas. Rataan suhu lingkungan saat itu $25,57^{\circ} \mathrm{C}$ sampai dengan $35,03^{\circ} \mathrm{C}$. Hasil ini tidak berbeda jauh dari yang dilaporkan Mangkuwidjojo (1988) bahwa daerah nyaman bagi kambing berkisar antara $18^{\circ} \mathrm{C}$ dan $30^{\circ} \mathrm{C}$ di mana suhu tubuh kambing pada kondisi normal $38,5-40^{\circ} \mathrm{C}$ dengan rataan $39,4^{\circ} \mathrm{C}$ atau antara 38,5 dan $39,7^{\circ} \mathrm{C}$ dengan rataan $39,1^{\circ} \mathrm{C}$.

Panas yang dihasilkan dari proses metabolisme dalam tubuh akan dibawa oleh sirkulasi darah ke permukaan tubuh untuk cekaman pada waktu siang hari dan kembali pada sore hari. Menurut Anggorodi (2004) bahwa pengukuran kecernaan atau nilai cerna suatu bahan merupakan usaha untuk menentukan jumlah nutrient dari suatu bahan yang didegradasi dan diserap dalam saluran pencernaan. Daya cerna merupakan persentase nutrien yang diserap dalam saluran pencernaan yang hasilnya akan diketahui dengan melihat selisih antara jumlah nutrien yang dikonsumsi dengan jumlah nutrient yang dikeluarkan dalam feses. Tinggi rendahnya kecernaan bahan pakan memberi arti seberapa besar bahan pakan itu mengandung zat-zat makanan dalam bentuk yang dapat dicerna dalam saluran pencernaan (Ismail, 2011).

\section{Pengaruh Cekaman Panas terhadap Kecernaan Bahan Organik Kambing Kacang Jantan}

Bahan organik yaitu bahan kering yang sudah dikurangi abu, unsur-unsur bahan kering yang difermentasi ke dalam rumen menghasilkan asam lemak terbang sebagai sumber energi bagi ternak. Nilai kecernaan bahan organik (KBO) diperoleh dengan jalan perbandingan kandungan bahan organik (BO) awal sebelum inkubasi dan sesudah inkubasi, proporsional terhadap kandungan bahan organik sebelum diinkubasi (Blummel dkk., 1997). 
Bahan makanan (pakan) ialah bahan yang dapat dimakan, dicerna dan digunakan oleh hewan. Komponen-komponen yang dikandung oleh bahan makanan disebut zat makanan. Pada saluran pencernaan ternak kecernaan bahan organik meliputi kecernaan zat-zat makanan seperti karbohidrat, protein, lemak, dan vitamin. Bahan-bahan organik tersedia dalam bentuk tidak larut sehingga dibutuhkan proses pemecahan menjadi zat-zat yang mudah larut. Kecernaan bahan organik dipengaruhi oleh beberapa faktor antara lain kandungan mineral dan serat kasar dari bahan pakan. Kecernaan bahan organik dan bahan kering sangat berkaitan karena sebagian dari bahan kering terdiri dari bahan organik (Ismail, 2011).

Hasil penelitian kecernaan bahan organik kambing kacang jantan dapat dilihat pada Tabel 2.

Tabel 2. Kecernaan Bahan Organik Kambing Kacang Jantan (\%)

\begin{tabular}{lcc}
\hline & \multicolumn{2}{c}{ Perlakuan } \\
\cline { 2 - 3 } Variabel & Tanpa Naungan & Naungan \\
\hline Kecernaan BO $(\%)$ & $54.27 \pm 10.18$ & $50.11 \pm 14.62$ \\
\hline Keterangan: Tidak signifikan $(P>0,05)$ &
\end{tabular}

Adapun rataan persentase kecernaan bahan organik pada Tabel 2 dari kelompok ternak yang tanpa naungan adalah $54,27 \pm 10,18$ sedangkan yang bernaungan adalah 50,11 $\pm 14,62$. Meskipun terlihat berbeda namun hasil uji statistik menunjukkan bahwa persentase kecernaan bahan organik dari kedua kelompok perlakuan tidak berbeda nyata $(\mathrm{P}>0,05)$.

Pengaruh tidak berbeda nyata disebabkan karena bahan organik merupakan komponen dari bahan kering sehingga faktor-faktor yang memengaruhi tinggi rendahnya kecernaan bahan kering akan memengaruhi tinggi rendahnya kecernaan bahan organik dalam suatu pakan. Pendapat ini sesuai dengan pernyataan Sutardi (1990) yang menyatakan bahwa peningkatan kecernaan bahan organik sejalan dengan peningkatan kecernaan bahan kering sehingga faktor-faktor yang memengaruhi tinggi rendahnya bahan kering akan memengaruhi tinggi rendahnya bahan organik.

Hal ini dapat dimaklumi karena bahan organik merupakan komponen terbesar dari bahan kering. Pernyataan tersebut didukung dengan pendapat Murni dkk, (2012) menyatakan bahwa tinggi rendahnya konsumsi bahan organik akan dipengaruhi oleh tinggi rendahnya konsumsi bahan kering. 
Daya cerna bahan organik berkaitan erat dengan konsumsi bahan kering. Paramita dkk.,(2008) menyatakan bahwa jumlah pakan akan memengaruhi kecernaan. Kecernaan sangat erat kaitannya dengan konsumsi pakan. Dengan demikian, tidak adanya perbedaan antara daya cerna bahan kering dan organik juga disebabkan oleh tidak terdapatnya perbedaan dalam konsumsi bahan kering dan bahan organik perlakuan.

Sejalan dengan pernyataan McDonald dkk.,(1995), bahwa pada bahan pakan ternak hijauan maupun konsentrat tersusun dari fraksi bahan kering dan bahan organik. Tillman dkk.,(1989) juga menyatakan bahwa bahan organik erat kaitannya dengan bahan kering, karena bahan organik merupakan bagian dari bahan kering.

Hal ini sesuai dengan pernyataan bahwa nilai kecernaan bahan organik berkaitan erat dengan bahan kering ransum. Sebab sebagian besar komponen dari bahan kering ransum terdiri dari bahan organik (Tilman dkk.,1998). Secara statistik data kecernaan bahan organik apabila dihubungkan dengan kecernaan bahan kering maka hasilnya juga akan saling mengikuti. Kecernaan bahan kering dengan sendirinya akan memengaruhi kecernaan bahan organik (Tilman dkk.,1982). Hal ini disebabkan karena kandungan bahan organik suatu bahan pakan terakumulasi di dalam bahan kering. Bahan organik terdiri dari serat kasar, lemak kasar, protein kasar, BETN, sedangkan bahan kering tersusun atas serat kasar, lemak kasar, protein kasar, BETN, dan abu (Kamal, 1994).

\section{SIMPULAN DAN SARAN}

Kesimpulan yang diperoleh dari penelitian ini adalah sebagai berikut: a). Rataan persentase kecernaan bahan kering pada kelompok ternak yang tanpa naungan adalah $56.43 \pm 4,31 \%$ sedangkan yang bernaungan adalah $59,61 \pm 3,21 \%$. b). Rataan persentase kecernaan bahan organik pada kelompok ternak yang tanpa naungan adalah $54,27 \pm 10,18$ sedangkan yang bernaungan adalah $50,11 \pm 14,62$.

Saran yang dapat disampaikan adalah membuat produk pakan komplit berbasis gamal untuk kambing kacang agar mendapatkan tingkat kecernaan yang lebih baik lagi.

\section{DAFTAR PUSTAKA}

Anggorodi, R. 2004. Ilmu Makanan Ternak Dasar. Gadjah Mada University Press, Yogyakarta. 
Al-Dawood, A. 2017. Toward heatstress management in small ruminant-a review. Ann.Anim.Sci, vol: 17, No. 1 (2017) 59-88, DOI: 10.1515/aoas-2016-0068. Diakses 28 April 2018.

Blümmel, M., H. Steingass dan K. Becker. 1997. The relationship between in vitro gas production, in vitro microbial biomass yield and $15 \mathrm{~N}$ incorporated and its implication for theprediction of voluntary feed intake of roughages. Br. J. Nutr. 77: 911-921.

Chaidanya, K., Soren, N.M., Sejian, V., Bagath, M.B. Manjunatareddy, E.K. Kurien, G. Varma, and R. Bhatta. 2017. Impact of heat stress, nutritional stress and combined (head and nutritional) stresses on rumen associated fermentation characteristics, histopathology and HSP70 gene expression in goats. ISSN 2318-1265. J. Anim Behav Biometeorol (2017) 5:36-48.http://dx.doi.org/10.14269/2318-1265/jabb.v5n2p36-48. Diakses 28 April 2018.

Dhana K.R. 2008. Pengaruh penggunaan hidrolisat tepung bulu ayam dalam ransum terhadap kecernaan bahan kering dan bahan organik serta konsentrasi amonia cairan rumen kambing kacang jantan. Fakultas pertanian universitas sebelas maret Surakarta.

Ismail, R. 2011. Kecernaan In Vitro, http://rismanismail2. wordpress. com/ 2011/05/22/nilai-kecernaan-part-4/\#more-310. [Rabu, 13 Februari 2013].

Jems. A. Momot, K. Maaruf, M. R. Waani, Ch. J. Pontoh, 2014. Pengaruh penggunaan konsentrat dalam pakan rumput benggala (panicummaximum) terhadap kecernaan bahan kering dan bahan organik pada kambing lokal. Jurnal zootek ("zootek journal”) vol 34 (edisi khusus): 108- 114 (Mei 2014). ISSN 0852-2626.

Kamal, M. 1994. Nutrisi Ternak I. Fakultas Peternakan . Gadjah Mada University Press. Yogyakarta.

Mangkuwidjojo. 1988. Bersahabat Dengan Hewan. Gadjah Mada Universitas Press. Yogyakarta.

McDonald, P., Edwards, R.A., Greenhalgh, J.F.D., Morgan, C.A.. 1995. Animal Nutrition. Fifth Ed. John Willey and Sons, Inc, New York.

Murni, R., Akmal, dan Y. Okrisandi. 2012. Pemanfaatan kulit buah kakao yang difermentasi dengan kapang phanerochaete chrysosporium sebagai pengganti

Rahman, D. K. 2008. Pengaruh Penggunaan Hidrolisat Tepung Bulu Ayam dalam Ransum terhadap Kecernaan Bahan Kering dan Bahan Organik serta Konsentrasi Amonia Cairan Rumen Kambing Kacang Jantan. Skripsi. Program Studi Peternakan Universitas Sebelas Maret.

Sireli, H.D., M. Tutkun, A.M. Tatar, and s.s. Tuncer. 2017. Heat Stress inruminants. Scierntific Papers. Series D Animal Science. Vol. LX, 2017.ISSN Online 2393-2260. Diakses 28 April 2018. 
Suparman. 2007. Beternak Kambing. Azka Press. Jakarta

Sutardi, T. 1990. Landasan Ilmu Nutrisi. Depertemen Ilmu Makanan Ternak, Fakultas Pertanian,IPB Bogor.

Tillman, A.D., H. Hartadi., S. Reksohadiprodjo., S. Prawirokusumo., dan S Lebdosoekojo., 1998. Ilmu 24 Makanan Ternak Dasar. Gadjah Mada University Press, Yogyakarta. 